\title{
The Analysis of Interest Rate Pricing and Its Impact on P2P Platform in the Scalper Arbitrage Environment
}

\author{
Jianqing Huang, Xiao Liu \\ University of International Business and Economics, Beijing, China \\ Email: jianqinghuang@126.com, liuxiao@uibe.edu.cn
}

How to cite this paper: Huang, J.Q. and Liu, X. (2018) The Analysis of Interest Rate Pricing and Its Impact on P2P Platform in the Scalper Arbitrage Environment. Open Journal of Social Sciences, 6, 166-179. https://doi.org/10.4236/jss.2018.64015

Received: March 12, 2018

Accepted: April 24, 2018

Published: April 27, 2018

Copyright $(9) 2018$ by authors and Scientific Research Publishing Inc. This work is licensed under the Creative Commons Attribution-NonCommercial International License (CC BY-NC 4.0).

http://creativecommons.org/licenses/by-nc/4.0/ cc) (i) \& Open Access

\begin{abstract}
At present, China's P2P platform has emerged a group of people known as net loan scalper. They borrowed money at low interest rates and invested the high interest rates loans in order to earn profit margins. This paper intends to discuss the factors influencing the loan interest rate into the scalper arbitrage environment from the microcosmic point of view, and focuses on the construction of multiple regression model of 35,970 real transaction data from Hongling Capital, and confirmed that the amount of loan, the term of loan, the mode of repayment, the type of the subject and the lowest bid limit have a significant impact on the setting of the loan interest rate, as well as in the scalper arbitrage environment and no scalper arbitrage environment, the impact of these variables are different. Therefore, platform and users should treat the scalper arbitrage dialectically and learn to identify the risks behind it so as to avoid them.
\end{abstract}

\section{Keywords}

P2P Lending, Interest Rate, Scalper, Arbitrage, Hongling Capital

\section{Introduction}

P2P network lending refers to a financial model in which a third-party network platform acts as a middleman and provides small loans to individuals on the premise of collecting certain interest. The first P2P lending platform in the world was Zopa, which was launched in London in March 2005. Subsequently, the United States launched the global large-scale P2P Lending platforms such as Prosper and Lending Club. In China, due to the difficulty of lending to small and micro enterprises or personal in financial market, the emergence of P2P online 
loan platforms has mushroomed rapidly. The earliest P2P lending platform was Credit Ease, which was put into operation in May 2006, and then lending platforms such as PPdai, Hongling Capital and Renrendai were successively appeared. In 2013, it was called "the first year of Internet finance" in China. The total volume of transactions in the whole industry was 3.9 trillion yuan in 2017. From the volume of transactions, P2P has become the most important part of Internet finance. Internet finance has been written into the government's work report twice and pointed out that it is necessary to promote the healthy development of Internet finance. The P2P lending market has become an increasingly important part of China's financial market. However, as market demand continues to expand, the P2P lending platform itself faces many challenges. As of December 30, 2017, there were a total of 3411 P2P platforms suspension in China, and the incidence of business suspension and problem platforms was as high as $67.65 \%$. This shows that the development of P2P lending in China is still a long way to go.

The development of P2P lending Platform in China is greatly of "Chinese characteristics" in recent years. There are a small number of people on P2P platform who take advantage of their credit and the leverage policy of the platform to borrow money at low interest rate, and then lend it out at high interest rate, which leads to a cyclic process. This phenomenon is called "scalping on P2P platform" and this type of people is called "scalpers". The existence of scalpers comes with plenty of problems. As long as there are one or more overdue loans or bad debts, the whole capital chain will break, resulting in a huge disaster for both investors and the platform due to the wide involvement. With the new supervision mechanism for $\mathrm{P} 2 \mathrm{P}$, the activities of scalpers are under the legal supervision. Hence there are many disputes about the scalping, which is well worth further observation and study.

As one of the most important parts of Internet financial development, the risk control of P2P plays an important role in enhancing the confidence of investors and promoting the inflow of investment funds. Interest rate is one of the most important price variables in the financial market. It directly determines the pricing of related financial products and the management of interest rate risk and has great significance in the market of capital financing. However, the current domestic research on P2P net loan interest rate is less, and the research focused on the common market environment underlying loan borrower information for the impact of interest rates and lacked of the research on the factors in the scalper arbitrage environment. Therefore, this paper based on Hongling Capital, such an open, free pricing P2P platform, explores the factors that significantly influence the interest rates in the scalper arbitrage environment compared with no-arbitrage market, and the possible impacts of the arbitrage on users, platforms, and the market. Suggestions for investors and borrowers on P2P platform are given according to the observation and analysis of the experimental results. 


\section{Literature Reviewed}

At present, the research in the field of $\mathrm{P} 2 \mathrm{P}$ can be divided into two main angles: the borrower's angle and the investor's angle. From the borrower's point of view, Gregor N.F. (2010) [1] and Serranocinca C. (2015) [2] found the amount of the loan, the borrower's credit rating, the maturity of the loan have a significant impact on the loan interest rate, in which the loan interest rate is negatively related to the success rate of borrowing (Puro, 2010) [3], and borrowers who publish their jobs, education, and other personal information are more likely to be favored by investors (Fabian Prystav, 2016) [4]. Similarly, communities that provide high quality structured signals and high-quality behavioral signals are likely to borrow at low interest rates (Collier, 2010) [5]. In China, some people believe that the majority of investors and financiers do not have the ability to identify risks because of they are used to fixed interest rates (Z. Zhang, X. Hu, 2013) [6], the other people think the credit rating authentication mechanism set up by P2P net lending platform can fully demonstrate the borrower's credit situation and play a certain role in avoiding risks for investors (H. Wang, L. Liao, 2014) [7]. In addition, the platform information can be divided into the basic attributes of loan orders and the basic information of borrowers (Y. Li, Y. Guo, W. Zhang, 2013) [8]. The borrower's residence, personal life, education and income are significantly related to overdue loan (X. Chen, X. Ding, B. Wang, 2013) [9], and the borrower's educational background is negatively related to the default rate (L. Ji, W. Zhang, 2015) [10], and the more successful the borrower's work experience or higher education level, the higher the success rate of borrowing (W. Sun, X. Fan, 2016) [11]. Borrowers using real names have lower borrowing success rates and higher default rates than borrowers who use network nicknames (F. Guo, 2016) [12], and borrowers with lower credit ratings tend to add borrowing descriptions to reduce information asymmetry between investors and borrowers (L. He, H. Wang, 2015) [13]. In addition, the borrower's interest rate is still affected by the interest rate of the bank (F. Jiang, H. Zhang, 2016) [14]. An increase in the risk of bank run in the traditional banking sector increases participation in the P2P markets and reduces their rates (E. Faia, M. Paiella, 2016) [15]; Also, there is a negative correlation between the borrower's credit rating, the amount of the loan and the loan interest rate, and the historical flow times are positively related to the loan interest rate (J. Li, J. Zhu, 2013) [16]. At the same time, the higher the interest rate on the loan order, the greater the default risk (J. Zhou, X. Zhang, 2016) [17]. What's more, C. Xiao, B. Huang, and D. Ye (2017) [18] found that the amount of punctuations is negatively associated with the funding probability and borrowing rate.

From the angle of investors, researchers explore the behavior of investors in the market whether it is rational through the analysis of investors' herding and perception of trust, thus to guide the investment behavior. D. Shen (2010) [19] has found that there is a clustering effect when investors make lending decisions. And in P2P social relationships, borrowers who have more friends are more 
likely to be favored by investors (Li S., Lin Z., 2015) [20]. Carlos and Begoña (2016) [21] use multiple regression method to build a new profit scoring system to help investors better to select borrowers. In addition, some interesting studies have found that young borrowers receive relatively small amounts of investment, and that the attractiveness of the borrower's avatar will play a key role (Gonzalez, 2014) [22]. At home, Investors' behavior also has obvious characteristics. In the lending relationship, regional discrimination is obvious and investors are more inclined to lend money to borrowers in high-income areas (Y. Jiang, A. Zhou, 2016) [23]. Also investors prefer items with short loan terms or repayment methods (J. Wu, 2016) [24]. L. Miu, J. Chen (2014) [25] through studying the small and medium-sized group mechanism, friend mechanism and recommendation mechanism of foreign P2P platform, concluded that the default risk of the group joining or good circle of friends is relatively low. From the perspective of social cognition of investors, D. Chen (2014) [26] concludes that investor perception of trust is positively affected by borrower's information quality and platform security level. Also, L. Zhuang (2015) [27] uses game theory to analyze the process of borrowing and investing, which suggests that borrowers and investors can reduce costs or identify risks through constant learning.

Above all, foreign scholars pay more attention to the historical behavior of borrowers and investors. Domestic scholars study from the perspective of platform participants, without taking into account the existence of special participants such as scalper. This paper divided the participants on the P2P platform into ordinary participants and scalpers to explore the key factors affecting loan interest rate setting in scalper arbitrage environment.

\section{Research Models and Hypotheses}

\subsection{Research Situation}

The case study of this paper is Holing Capital. Holing Capital, with active trading and various financing products, is the first to release the "net loan". Net loan was initially set up for those users with balance to be collected, to acquire the borrowing limit $90 \%$ of their net account from the platform, when they have demand for temporary funds or capital flow issues, and the net loan will automatically pass the review of the platform. However, some investors, who found the arbitrage opportunity to profit from the interest rate differential, have perceived the high leverage of net loan. The high leverage of Holing Capital's investment regulations provide scalpers with good arbitrage environment. According to the Hongling Capital Scalping Report posted by Holing Capital official micro-blog on February 19, 2016, there had been 16,057 investors with borrowing records on Hongling Capital platform by January 31, 2016, 6163 of which were scalpers; the scalpers accounted for $38.4 \%$ of investors with borrowing records. Hongling Capital is thus representative for the study of scalpers on online $\mathrm{P} 2 \mathrm{P}$ platform. 


\subsection{Data Preparation}

In this paper, we captured the dynamic data from Hongling Capital platform between March 1, 2015 and August 31, 2015 and got more than 50 thousand transaction data. After data arrangement, there are 35,970 valid data. Around 2015, P2P lending showed a brutal growth trend and developed rapidly, and the net loan scalpers on various platforms were active. The use of data from this time period to study scalper behavior has a strong representation.

We used the grouping regression method and divided the data into scalper group and non-scalper group. According to official definition of Hongling Capital: the amount to be repaid $\geq 10$ million is defined as scalpers. Accordingly, the data are processed using a PivotTable and finally got 35,970 valid data. There are 4792 samples of scalper and 894 scalper borrowers ID, accounting for $35.6 \%$ of the total sample data (2508 borrowers ID).

\subsection{Variable}

In $\mathrm{P} 2 \mathrm{P}$ net lending transactions, borrowers tend to have more information than investors. In order to alleviate the phenomenon of asymmetric information, the platform will require borrowers to provide subject information and some personal information. From the perspective of borrowers, this paper selects two factors that affect borrowers' interest rate: One is the loan characteristics, including 6 types of variables, interest rate, borrowing period, investment limit, borrowing amount, repayment and bidding-type; the other is personal characteristics, including 1 variables that is whether for VIP users.

Explained variable:

Interest rate: It's the annualized rate of interest that borrowers on the P2P lending platform are willing to pay in order to succeed in obtaining loans.

Explanatory variable:

1) Amount of loan: borrowers will set the loan amount according to their actual needs, but in order to be able to successfully raise funds or faster to raise funds, the borrower may consider by changing interest rates to compensate for the impact on the success of the loan amount.

2) Term of loan: the term of loan is referred to the time limit to pay the debt on Hongling Capital platform. The loan term of general loans varies from five days to one year. The platform to collect data keeps the record by day, month, and year, so "day" is the unified unit to process data according to the principle "one month is equal to 30 days" and "one year is equal to 365 days".

3) Mode of repayment: Hongling Capital repayment methods include one-time repayment, monthly installments, monthly maturity and quarterly.

4) Bidding-type: Hongling Capital mainly includes 7 different types of targets. The sample number of net loan subject accounted for more than $80 \%$ of the sample data obtained in this paper, so this will be the subject type as dummy variable. We set net loan standards to 1, other types of borrowing targets are set to 0 . 
5) Whether for VIP users: Users can become VIP users by paying membership fees. When setting interest rates, VIP users and non-VIP users may have different rates of interest, taking into account the cost costs.

6) Investment limit: Hongling Capital in order to regulate the amount of investment, requiring borrowers to issue loans when the subject to set a minimum investment limit, investors need to invest in accordance with the limit, the amount of investment cannot be less than the limit. Based on the analysis of the data obtained, the minimum investment is divided into three parts: 50 - 100; 100 $1000 ; 1000-10000$.

\subsection{Research Models and Hypotheses}

Sharp et al. (1964) [28] points out that in a frictionless market environment, when the market reaches equilibrium, there is a linear relationship between risk and return. We can understand that if we are in a balanced market, we can analyze the risks behind it by looking at interest rates. And according to the arbitrage pricing theory, the return rate of risky assets can be produced by several factors, and there is a linear relationship with many common factors. The yield generation process of any asset can be represented by a linear function: $E R=\lambda_{0}+\lambda_{1} b_{i 1}+\lambda_{2} b_{i 2}+\cdots \lambda_{i} b_{i k}+\varepsilon \quad$ (R. Wang, 2010) [29].

The arbitrage-pricing model has the following hypotheses: 1) the capital market is completely competitive, without friction. At present the P2P market has not reached the market equilibrium and the borrower combine its own situation to set the interest rate in order to obtain the loan. But through the research on the interest rate risk identification of incomplete market, L. Liao, M. Li (2014) [30] find that although the interest rate setting of P2P net loan market is not completely marketization, loan interest rate partially reflects the default risk of borrowers. 2) Investors are seeking returns, but they are also averse to risk. Paravisini D., Rappoport V. and Ravina E. (2010) [31] using the curvature of the utility function of investors to estimate the risk appetite of investors, and through the establishment of panel data found that more wealthy investors more risk averse, and less wealth will be more risk averse. Therefore, investors will be aware of the risk of a conscious avoidance. 3) Investors can find out whether there are arbitrage opportunities in the market and seize the opportunity. In Hongling Capital platform, net loan scalper has become a profession. Scalpers have rich professional knowledge, high credit and carry out the arbitrage activities all day, which cost a lot of time and energy.

Based on the above theoretical framework analysis, this paper constructs the influencing factors model of the interest rate pricing of the mortgage in the scalper arbitrage environment:

$$
\begin{aligned}
\text { interest }= & \alpha+\beta_{1} \text { amount }+\beta_{2} \text { tern }+\beta_{3} \text { repay }- \text { methed } \\
& +\beta_{4} \text { range }+\beta_{5} \text { bidding }- \text { type }+\beta_{6} \text { vip }+\mu
\end{aligned}
$$

Based on the above research models and variables, the following hypotheses are proposed: 
H1: Scalper market interest rate is less than non-scalper market interest rate. Since the scalpers are mainly profit-making by issuing low-interest borrowing targets and investing in high-yield bids to earn interest rate differentials, it is assumed that the overall borrowing interest rate after exclude scalper will be relatively improve.

$\mathrm{H} 2$ : The average borrowing amount in the scalper market is less than the average borrowing amount of the non-scalper market. In order to guarantee the success of raising funds or to raise funds more quickly, scalpers usually set a smaller amount of loan.

H3: The scalper market borrowing period is less than non-scalper market borrowing period. In order to guarantee the success of raising funds or to raise funds more quickly, scalpers usually set short-term borrowing time. Therefore, assuming that the scalper data is excluded from the online loan market, the overall borrowing period will be relatively increased.

H4: The greater the amount of the loan, the higher the interest rate on the loan, and in the scalper market, changes in the amount of borrowing affect interest rates more than the non-scalper market.

$\mathrm{H} 5$ : The longer the loan period, the higher the lending rate, and in the scalper market, changes in the loan period affect interest rates more than the non-scalper market.

H6: The rate of one-time repayment is lower than that of other installments.

H7: The higher the minimum investment limit, the higher the interest rate, and the changes in the minimum investment limit in the scalper market have more impact on the lending rate than the non-scalper market.

H8: The interest rate set by the net loan value is lower than that of other types of borrowing.

H9: VIP users have higher loan interest rates than non-VIP users.

\section{Empirical Analysis}

\subsection{Descriptive Statistics}

The results of descriptive statistics are shown in Table 1. INTEREST, AMOUNT and TERM respectively loan interest rate, the amount of loan and the term of loan, and 1 representatives including scalper data, 2 representative data after excluding scalper.

As shown in Table 1, the average interest rate in the scalper market is lower than the average interest rate in the non-scalper Market $(13.83 \%>13.45 \%)$. As H1 shows, scalpers mainly through the issuance of low interest rates, and invest in high interest rates to earn profit margins from them, after excluding scalper data, the overall loan interest rates will be relatively higher. And because of the skewness of the two borrowing rates is less than zero, the lending rate is skewed to the left. What's more, the kurtosis of AMOUNT-1 is $4.067>0$, and the kurtosis of AMOUNT-2 is $1.003>0$, as a result, the lending rate is in a peak state, and the scalper market is steeper than the non-scalper market. 
Table 1. The results of descriptive statistics.

\begin{tabular}{cccccccc}
\hline & \multicolumn{2}{c}{$\mathrm{N}$} & \multicolumn{2}{c}{ Mean(E) } & \multicolumn{2}{c}{ Skewness } & \multicolumn{2}{c}{ Kurtosis } \\
\cline { 2 - 8 } & Statistic & Statistic & Std. Error & Statistic & Std. Error & Statistic & Std. Error \\
\hline INTEREST-1 & 35,970 & 13.45 & 0.012 & -1.869 & 0.013 & 4.067 & 0.026 \\
AMOUNT-1 & 35,972 & $24,247.3191$ & 183.80065 & 3.802 & 0.013 & 30.113 & 0.026 \\
TERM-1 & 35,972 & 36.690 & 0.2555 & 4.234 & 0.013 & 20.433 & 0.026 \\
INTEREST-2 & 31,179 & 13.83 & 0.009 & -1.019 & 0.014 & 1.003 & 0.028 \\
AMOUNT-2 & 31,181 & $29,510.9871$ & 158.11557 & 3.764 & 0.014 & 49.518 & 0.028 \\
TERM-2 & 31,181 & 43.762 & 0.3282 & 3.453 & 0.014 & 12.865 & 0.028 \\
\hline
\end{tabular}

Secondly, the amount of the online lending market containing scalpers is $24,247.3191$, which is slightly lower than the average amount of $29,510.9871$ in the market without scalpers. Under normal circumstances, scalpers will generally set small amount of loan in order to ensure the success or speed of fund raising. However, the result shows that the two numbers only have slight difference, indicating that the participation of scalpers has no obvious impact on the amount borrowed in the whole online lending market. The specific reasons need further verification.

Lastly, the average loan term of the market containing scalpers is 36.69 , lower than the number of 43.762 in non-scalpers market, which conforms to H3. Scalpers usually set shorter loan terms in order to increase the possibility of loan success, so the loan term of the whole market will increase after removing the scalpers. In addition, the skewness of TERM-1 is 4.234, and the skewness of TERM-2 is 3.453, both of which are above the zero, indicating that the distribution of loan term is right-skewed, and the borrower is more inclined to set the term of loan for more than 1 months.

\subsection{Regression Analysis}

In order to study the factors that influence the setting of the loan interest rate in the scalper arbitrage environment, this paper collected the Hongling Capital data, and used SPSS software to do multiple linear regression analysis.

According to Table 2 and Table 3, the F are 3317.126 and 2695.103, respectively, and the corresponding $\operatorname{Sig}<0.001$. Given that $\alpha=0.01$ is obviously $\mathrm{p}<\alpha$, it is assumed that the linear regression equation is significant.

According to Table 4 and Table 5: 1) In scalper market and non-scalper market, the regression coefficient of the loan amount is highly significant, and the loan amount is positively related to the loan interest rate, as $\mathrm{H} 4$ shows (AMOUNT-1, B = 1.273E-6, p < 0.01; AMOUNT-2, B = 5.095E-6, $\mathrm{p}<0.01$ ). However, since the regression coefficients of the loan amount in the two models are very small, the increase in the borrowing amount per unit is so small that the borrowing rate can be neglected. So we can think, whether or not the presence of scalper, the amount of loans on loan interest rates is the same. 
Table 2. ANOVA (including scalper data).

\begin{tabular}{ccccccc}
\hline \multicolumn{1}{c}{ Model } & Sum of squares & Df & Mean Square & F & Sig. \\
\hline & Regression & $70,129.173$ & 6 & $11,688.195$ & 3317.126 & $0.000^{\mathrm{b}}$ \\
1 & Residual & $126,718.898$ & 35,963 & 3.524 & & \\
& Total & $196,848.071$ & 35,969 & & & \\
\hline
\end{tabular}

Table 3. ANOVA (excluding scalper data).

\begin{tabular}{|c|c|c|c|c|c|c|}
\hline & Model & Sum of squares & Df & Mean square & $\mathrm{F}$ & Sig. \\
\hline \multirow{3}{*}{2} & Regression & $24,347.984$ & 6 & 4057.997 & 2695.103 & $0.000^{\mathrm{b}}$ \\
\hline & Residual & $46,933.945$ & 31,171 & 1.506 & & \\
\hline & Total & $71,281.929$ & 31,177 & & & \\
\hline
\end{tabular}

Table 4. Significance test of regression coefficient (including scalper data).

\begin{tabular}{|c|c|c|c|c|c|c|c|c|}
\hline & \multirow{2}{*}{ Model } & \multicolumn{2}{|c|}{$\begin{array}{c}\text { Unstandardized } \\
\text { Coefficients }\end{array}$} & \multirow{2}{*}{$\begin{array}{c}\begin{array}{c}\text { Standardized } \\
\text { Coefficients }\end{array} \\
\beta\end{array}$} & \multirow[t]{2}{*}{$\mathrm{T}$} & \multirow{2}{*}{ Sig. } & \multicolumn{2}{|c|}{$\begin{array}{c}\text { Collinearity } \\
\text { Statistics }\end{array}$} \\
\hline & & B & Std. Error & & & & Tolerance & VIF \\
\hline \multirow{7}{*}{1} & (Constant) & 10.558 & 0.146 & & 72.430 & 0.000 & & \\
\hline & AMOUNT-1 & $1.273 \mathrm{E}-6$ & 0.000 & 0.029 & 6.899 & 0.000 & 0.994 & 1.007 \\
\hline & TERM-1 & 0.007 & 0.000 & 0.139 & 32.465 & 0.000 & 0.980 & 1.020 \\
\hline & REPAY-METHD-1 & 1.536 & 0.012 & 0.555 & 129.392 & 0.000 & 0.972 & 1.029 \\
\hline & RANGE-1 & -1.025 & 0.118 & -0.037 & -8.724 & 0.000 & 0.999 & 1.001 \\
\hline & BIDDING-TYPE-1 & -0.342 & 0.081 & -0.018 & -4.208 & 0.000 & 0.987 & 1.013 \\
\hline & VIP-1 & 0.413 & 0.020 & 0.087 & 20.474 & 0.000 & 0.992 & 1.008 \\
\hline
\end{tabular}

Table 5. Significance test of regression coefficient (Excluding scalper data).

\begin{tabular}{|c|c|c|c|c|c|c|c|c|}
\hline & \multirow{2}{*}{ Model } & \multicolumn{2}{|c|}{$\begin{array}{l}\text { Unstandardized } \\
\text { Coefficients }\end{array}$} & \multirow{2}{*}{$\begin{array}{c}\begin{array}{c}\text { Standardized } \\
\text { Coefficients }\end{array} \\
\beta\end{array}$} & \multirow{2}{*}{$\mathrm{T}$} & \multirow{2}{*}{ Sig. } & \multicolumn{2}{|c|}{$\begin{array}{c}\text { Collinearity } \\
\text { Statistics }\end{array}$} \\
\hline & & B & Std. Error & & & & Tolerance & VIF \\
\hline \multirow{7}{*}{2} & (Constant) & 11.579 & 0.061 & & 189.525 & 0.000 & & \\
\hline & AMOUNT-2 & $5.095 \mathrm{E}-6$ & 0.000 & 0.094 & 20.318 & 0.000 & 0.985 & 10.015 \\
\hline & TERM-2 & 0.002 & 0.000 & 0.059 & 12.688 & 0.000 & 0.981 & 10.020 \\
\hline & REPAY-MATHD-2 & 1.072 & 0.009 & 0.565 & 122.390 & 0.000 & 0.991 & 10.010 \\
\hline & RANGE-2 & 0.140 & 0.022 & 0.030 & 6.413 & 0.000 & 0.988 & 10.012 \\
\hline & BIDDING-TYPE-2 & -0.898 & 0.051 & -0.081 & -17.450 & 0.000 & 0.992 & 10.008 \\
\hline & VIP-2 & 0.192 & 0.014 & 0.062 & 13.489 & 0.000 & 0.985 & 10.015 \\
\hline
\end{tabular}

2) In the two markets, the borrowing period is positively related to the loan interest rate, as H5 (TERM-1, B = 0.007, $\mathrm{p}<0.01$; TERM-2, $\mathrm{B}=0.002, \mathrm{p}<0.01$ ), and in the $1 \%$ significant level, the two market borrowing period increased by 1 units, the loan interest rate will be increased by $0.007 \%$ and $0.002 \%$ respectively. 
3) In all the repayment methods, the one-time repayment of interest rates set minimum, as H6 (BIDDING-MATHED-1, B = 1.536, $\mathrm{p}<0.01$;

BIDDING-MATHED-2, $\mathrm{B}=1.072, \mathrm{p}<0.01$ ). According to the observation of the user comments of Hongling Capital community, the users are willing to facilitate financial management and overall management of investment funds. Compared to other repayment methods, one-time repayment is more favored by investors, so set minimum interest rates.

4) In the online lending market containing scalpers, the minimum borrowing limit is inversely proportional to interest rate on borrowings (RANGE-1, B $-1.025, \mathrm{p}<0.01$ ); in the market without scalpers, the minimum borrowing limit is in direct proportion to interest rate on borrowings (RANGE-1, B $=0.14, \mathrm{p}<$ 0.01). On the $\mathrm{P} 2 \mathrm{P}$ online lending platform, under normal circumstances, the lower the minimum borrowing limit, the smaller the investment threshold. When borrowers set the investment limit to a relatively high number, interest rate on borrowing needs to be increased accordingly in order to attract investment. This practice also applies in sectors like bank financing. However, scalpers will set relatively low minimum borrowing limit as well as increase the interest rate in order to borrow money in a short time and ensure the flow of fund, therefore, in the online lending market with scalpers, the minimum borrowing limit is inversely proportional to interest rate on borrowings.

5) The interest rate of net loan is set below the other loans, as H8 (BIDDING-TYPE-1, B $=-0.342, \mathrm{p}<0.01$; BIDDING-TYPE-2, $\mathrm{B}=-0.905, \mathrm{p}<$ 0.01 ). That is, under the significance level of $1 \%$, net loans correspond with lower interest rates. Because of the feature of net loans on Hongling Capital platform, users can acquire the borrowing limit $90 \%$ of their net account from the platform, and the net loan will automatically pass the review of the platform. This feature is used by scalpers who firstly invest in high-quality loan projects with high interest rates, then put out borrowing projects with low interest rates (compared with high-quality loan projects) after their balance accounts have $90 \%$ loan limit, and profit from the price differences. Thus, the ones who put out net loans are mostly scalpers, and the interest rates are lower than other types of loans.

6) The interest rates of VIP users are set above the non-VIP users, as H9 (VIP-1, B $=0.413, \mathrm{p}<0.01$; VIP-2, $\mathrm{B}=0.198, \mathrm{p}<0.01$ ). For borrowers, higher interest rates mean higher costs, but since the VIPs of Hongling Capital enjoy the benefits of lower management fees, and exchange of Hongbi (a kind of virtual currency), etc, to offset a part of costs, so VIPs are more likely to set higher interest rates to attract investors and successfully borrow money. On Hongling Capital platform, scalpers are all high-ranking VIPs with relatively more credits, because the higher the rank of the VIP, the less the cost of handling charge and management fee in multiple repeated transactions, and the more the Hongbi. Thus, whether the borrower is VIP or not, has greater influence on the market containing scalpers than the market without scalpers. 


\section{Conclusions and Recommendations}

As a product with Chinese characteristics that developed from domestic P2P field, the development pattern and regulating measures of scalper cannot draw on previous experience. The existence of scalpers is beneficial to the platform, because the frequent operation of scalpers can bring vitality and transactions to it. However, we must be aware of the disadvantages and potential risks. At first, most of the scalpers are active users with high level on the platform. By taking advantage of their level, they can take a lead in winning the biddings with high interest rate, which account for a part of high-profit resources for ordinary inventors. More importantly, the trading activities of scalpers have risks of capital chain rupture. It is horrible when the ruptures occur, because for general investors, the risk to bear is only their own principal and interest can be recovered. The circulative activities of scalpers by loaning with low interest rates and then inventing it in projects with high interest rates will increase the risks by several times. Once a contract breaks and bad debt occurs, the whole capital chain will rupture, bringing immeasurable losses to the investors and the platform.

Based on the real data of Hongling Capital, this paper analyzes the factors that affect loan interest rate under the circumstances of scalper interest arbitrage, and the influences of behaviors of P2P interest arbitrage on users, platform and market. On the basis of the research results, this paper gives the following recommendations to the investors, $\mathrm{P} 2 \mathrm{P}$ platform and other subjects in the entire industry:

1) The P2P industry and the supervision departments should play an active leading role in standardizing the development of the industry and stimulating market vitality. By strengthening the construction of credit infrastructure, including supporting for large data storage, allowing qualified institutions to access the financial credit information database, the transparency of the market information can be strengthened.

2) P2P platform should abide by the regulations of Internet financial industry and operate lawfully. Since 2016, P2P-related policies have been introduced in succession, and the central and local government all has enhanced the supervision of the legitimacy of each P2P platform. If the platform wants to survive in this wave of liquidation, it has to obey the law and regulations.

3) P2P platform should improve its specifications, and establish risk identification mechanism. It should issue corresponding regulations to regulate the behaviors of both borrowers and investors on the platform, and adopt early warning measures in advance to cope with potential risks. Facing the situation that scalpers seem to bring popularity and benefits to the platform, we cannot allow its unordered development, but to see the risks behind it and regulate the behaviors of scalpers.

4) The borrowers and investors on P2P platform can acquire more information about this industry, improve professional competence and make wiser investment strategies. 
However, there are still many deficiencies in the research process and we hope that we can continue to explore further in the follow-up study:

First, subject to sample size and diversity, this paper directly classifies borrowers as ordinary borrowers and net loan scalpers according to the standard that the amount to be repaid $\geq 10$ million. However, according to the official definition of Hongling Capital, the net loan scalpers are divided into four levels: Supers, Big, Middle and Small. The difference in the amount to be repaid of different levels of scalper is different, and there is a difference of nearly 10 million between the super scalper and the small scalper. In the future research, we can further study the impact of different levels of scalpers on the P2P platform and platform users, thereby standardizing the behavior of net loan scalpers and creating a good trading environment for the $\mathrm{P} 2 \mathrm{P}$ platform.

Second, this paper only studies the impact of net loan scalper as a borrower is one-sided, because in reality, scalper is not only a borrower, he is also an investor. Therefore, it should also continue to consider scalper as an investor's impact on the platform and users. Initially, the "lending willingness - interest rate" curve of normal investors is a parabola with a downward opening (K. Wang, 2013) [32]. That is, as the interest rate rises, investors' lending willingness also increases. But it is generally believed that high interest rate means high risk, therefore, when the interest rate reaches a certain amount, investors are in a risk-averse attitude and will reduce the investment in high interest rate project, and the investment in this project shows a rise in interest rates and a decrease in the willingness to lend. However, net scalpers need to invest in high-interest-rate project in order to earn interest rate spreads, and the risk avoidance attitude is weaker than that of general investors. Therefore, the addition of scalpers will make the "lending willingness - interest rate" curve shift to the right. As described above, the impact of net scalpers will need to be further proven and explored in future research.

\section{Acknowledgements}

This research was supported by the research project of Humanities and Social Science Research Program of Ministry of Education-Research on enterprise Internet financial development path and risk prevention-Based on platform economy perspective (14YJAZH035).

\section{References}

[1] Weiss, G.N.F. (2010) Mitigating Adverse Selection in P2P Lending-Empirical Evidence from Prosper.com. Social Science Electronic Publishing.

[2] Serranocinca, C., Gutiérreznieto, B. and Lópezpalacios, L. (2015) Determinants of Default in P2P Lending. Plos One, 10, e0139427.

https://doi.org/10.1371/journal.pone.0139427

[3] Puro, L., Teich, J.E., Wallenius, H., et al. (2010) Borrower Decision Aid for people-to-people lending. Decision Support Systems, 49, 52-60.

https://doi.org/10.1016/j.dss.2009.12.009 
[4] Prystav, F. (2016) Personal Information in Peer-to-Peer Loan Applications: Is Less More? Journal of Behavioral \& Experimental Finance, 9, 6-19. https://doi.org/10.1016/j.jbef.2015.11.005

[5] Collier, B.C. and Hampshire, R. (2010) Sending Mixed Signals: Multilevel Reputation Effects in Peer-to-Peer Lending Markets. ACM Conference on Computer Supported Cooperative Work, CSCW2010, Savannah, February 2010, DBLP, 197-206.

[6] Zhang, Z.P. and Hu, X.L. (2013) The Development of P2P: A Literature Review. East China Economic Management, No. 9, 159-164

[7] Wang, H.J. and Liao, L. (2014) Chinese P2P Platform's Credit Authentication Mechanism Research-Evidence from Renrendai. China Industrial Economica.

[8] Guo, Y. Analysis of Factors Affecting Loan Success Rate of P2P Small Loan Market in China. Tianjin University.

[9] Chen, X., Ding, X.Y. and Wang, B.F. (2013) A Study of the Overdue Behaviors in Private Borrowing-Empirical Analysis Based on P2P Network Borrowing and Lending. Finance Forum, No. 11, 65-72.

[10] Liao, L., Ji, L. and Zhang, W.Q. (2015) Education and Credit: Evidence from P2P Lending Platform. Journal of Financial Research, No. 3, 146-159.

[11] Sun, W.J. and Fan, X.Y. (2016) Whether the Experience and Educational Background Can Improve the Success Rate of Loan? Evidence from P2P Platform. Journal of Central University of Finance \& Economics, No. 3, 33-41.

[12] Guo, F. (2016) Success Rate and Default Rate of P2P Lending and Network Nicknames. Economic Science, No. 6, 102-116.

[13] Wang, H.J. and He, L. (2015) An Empirical Study of Borrowing Description's Influence on P2P Lending. Journal of Finance and Economics, No. 1, 77-85.

[14] Jiang, F.L., Zhang, H.L. and Tian, T.M.Z. (2016) P2P Network Lending Rate Determination-An Empirical Analysis Based on a Regional Platform. Shanghai Finance, No. 5, 60-64.

[15] Faia, E. and Paiella, M. (2017) P2P Lending: Information Externalities, Social Networks and Loans' Substitution. Social Science Electronic Publishing.

[16] Li, J. and Zhu, J. (2013) An Emprircal of Determinants of Interest Rate in P2P Lending Market. Journal of Guangdong University of Business, 28, 34-40.

[17] Zhou, J., Zhao, Z. and Zhao, X. (2016) Research on Default Risk of P2P Platform in China. Theory \& Practice, No. 5, 137-140.

[18] Xiao, C., Huang, B. and Ye, D. (2017) The Role of Punctuation in P2P Lending: Evidence from China. Economic Modelling, 68, 634-643.

[19] Shen, D., Krumme, C. and Lippman, A. (2010) Follow the Profit or the Herd? Exploring Social Effects in Peer-to-Peer Lending. 2nd International Conference on Social Computing, Minneapolis, 20-22 August 2010, 137-144.

[20] Li, S., Lin, Z., Qiu, J., et al. (2015) How Friendship Networks Work in Online P2P Lending Markets. Nankai Business Review International, 6, 42-67. https://doi.org/10.1108/NBRI-01-2014-0010

[21] Serrano-Cinca, C. (2016) The Use of Profit Scoring as an Alternative to Credit Scoring Systems in Peer-to-Peer (P2P) Lending. Decision Support Systems, 89, 113-122.

[22] Gonzalez, L. and Loureiro, Y.K. (2014) When Can a Photo Increase Credit? The Impact of Lender and Borrower Profiles on Online Peer-to-Peer Loans. Journal of Behavioral \& Experimental Finance, 2, 44-58. 
https://doi.org/10.1016/j.jbef.2014.04.002

[23] Jiang, Y. and Zhou, A. (2016) Does There Exist Regional Discrimination in P2P Lending? An Empirical Study on Renrendai. Journal of Central University of Finance \& Economics, No. 9, 29-39.

[24] Wu, J. (2015) Study on P2P Network Lending Model Based on Herding. Studies of International Finance, No. 11, 88-96.

[25] Miu, L. and Chen, J. (2014) The Influence of Social Capitals on Borrower's Default Risk in P2P Network Lending-A Case Study of the Proper. Finance Forum, No. 3, 9-15.

[26] Chen, D. (2014) A Study of Lending Trust in the Online Peer-to-Peer Lending Marketplace Based on Social Cognitive Theory. NanKai Business Review, 17, 40-48.

[27] Zhuang, L., Zhou, Q. and Wang, F. (2015) Interest Rate Liberlization, Effects on Learning by Doing and Efficiency of Network Lending. Journal of Finance and Economics, No. 5, 3-15.

[28] Sharpe, W.F. (1964) Capital Asset Prices: A Theory of Market Equilibrium under Conditions of Risk. The Journal of Finance, 19, 425-442.

[29] Wang, R. (2010) Arbitrage Pricing Theory and Its Empirical Analysis in Heavy Manufacturing Industry. Manager' Journal, No. 3, 89-90.

[30] Liao, L., Li, M. and Wang, Z. (2014) The Intelligent Investor: Not-Fully-Marketized Interest Rate and Risk Identify. Economic Research Journal, No. 7, 125-137.

[31] Paravisini, D., Rappoport, V. and Ravina, E. (2010) Risk Aversion and Wealth: Evidence from Person-to-Person Lending Portfolios. Nber Working Papers, 16063.

[32] Wang, K.Y. (2014) What Kind of Information Affects the Achievement of P2P Lending Transactions? Tsinhua University. 